Piśmiennictwo zakonne $w$ dobie staropolskiej, red. Magdalena Kuran, Katarzyna KaczorScheitler i Michał Kuran, przy współpracy Dawida Szymczaka, Łódź 2013.

Magdalena Kuran ${ }^{1}$

Uniwersytet Łódzki

\title{
Dzieła historyczne w XVII-wiecznym księgozbiorze oo. reformatów krakowskiego klasztoru św. Kazimierza
}

Reformacki księgozbiór w swym podstawowym charakterze nie odbiegał zasadniczo od zawartości innych klasztornych bibliotek. Zdominowany był, co oczywiste, przez dzieła teologiczne. Porządkowano je w działach, które określane były jako: Libri concionum, Libri spirituales, Libri in controversiis, Libri in casibus, Libri scholastici, Libri historici, Libri miscellanei, Libri Polonici, Libri historici profani Latini oraz Historici profani Polonici.

Zachowane XVII- (5) i XVIII-wieczne (3) indeksy biblioteki klasztoru św. Kazimierza w Krakowie pozwalają na refleksję nad charakterem kształcenia i duchowej formacji polskich reformatów. Przedmiotem refleksji będą prace historyczne obecne w zbiorach krakowskiego klasztoru. Zwraca bowiem uwagę spory ich udział w księgozbiorze ukierunkowanym przede wszystkim na kształcenie i formację zakonników: kaznodziejów, spowiedników i misjonarzy (tzw. ludowych).

W najstarszym zachowanym inwentarzu z roku 1648 wyodrębniony został dział Libri historici, podobnie w roku 1671. W kolejnym z 1689 roku mamy porządek alfabetyczny (według nazw osobowych) bez uwzględniania działów tematycznych. Rok 1693 przynosi inwentarz tematyczny, który jednak działu historycznego nie wyodrębnia. W roku 1712 historię uwzględniono w ramach szerszej grupy Libri scholastici, historii, oratorii et politici. W 1725 mamy niewielki dział nazwany znów Libri historici, zaś w 1727 dokonano już szczegółowszej specyfikacji. Wyodrębniono Libri historici Latini sacri, Libri historici sacri Polonici, Libri historici profani Latini oraz Historici profani Polonici.

Tak różne traktowanie dzieł historycznych, tj. ich wyodrębnianie bądź nie, umieszczanie ich $\mathrm{w}$ kategorii obok prac z zakresu scholastyki, oratorstwa i polityki, aby

\footnotetext{
${ }^{1}$ Dr Magdalena Kuran jest adiunktem w Katedrze Literatury Staropolskiej i Nauk Pomocniczych Uniwersytetu Łódzkiego. Doktorat uzyskała na podstawie rozprawy Retoryka jako narzędzie perswazji w postyllografii polskiej XVI w. (na przyktadzie "Postylli katolicznej” Jakuba Wujka) (Łódź 2007, Wydawnictwo UŁ). Publikowała w „Ruchu Literackim”, „Acta Universitatis Lodziensis. Folia Litteraria Polonica”, „Kościół w Polsce. Dzieje i Kultura”, „Liturgia Sacra”, „Studiach Źródłoznawczych” oraz w tomach pokonferencyjnych i okolicznościowych. Interesuje się prozą staropolską ze szczególnym uwzględnieniem kaznodziejstwa, jak też zastosowaniem retoryki w dawnych tekstach. Obecnie zajmuje się kaznodziejstwem franciszkanów-reformatów (F. Rychłowski, B. Gutowski, A. Węgrzynowicz i M. Łosiowic).
} 
w końcu dojść do pełniejszej specyfikacji, pokazuje też ewolucję historii jako dziedziny wiedzy, która wyodrębniła się z tzw. eruditiones i stała się w oświeceniu autonomiczną dziedziną wiedzy. Efektem tego było uczynienie historii odrębnym przedmiotem nauczania ${ }^{2}$.

Dzieła z zakresu historia sacra nie będą tu uwzględnione. Obejmowały one przede wszystkim historię Kościoła katolickiego, historię zakonu oraz hagiografię. Interesować mnie będzie tzw. historia profana. Warte uwagi jest też prześledzenie kierunku uzupełniania księgozbioru. Posłużą do tego inwentarze z roku 1648 (najwcześniejszy) oraz kolejny zachowany, z roku 1671. Są to jedyne spośród XVII-wiecznych indeksów reformackich, w których wyodrębniony jest dział Libri historici.

\section{HISTORYCY STAROŻYTNI}

1. Index totius Bibliothecae Patrum Reformatorum Conventus CRacoviensis ad SANCTUM CASIMIRUM ANNo DOMINI 1648

W najstarszym zachowanym indeksie w dziale Libri historici odnotowano w sumie 31 pozycji. Wśród historyków starożytnych znajdujemy Tytusa Liwiusza (59 p.n. e.17 n. e.) Ab Urbe condita tutaj jako Latinae historiae principis [382; in octavo 12] ${ }^{3}$, Swetoniusza (ok. 69-ok. 122) Żywoty Cezarów [382; in octavo 11], Juliusza Cezara (100 p.n.e.-44 p. n.e.) Commentarii rerum gestarum belli Gallici oraz Commentarii rerum gestarum belli civilis [382; in octavo 13] oraz Pliniusza Starszego (23n. e.-79n.e.) Naturalis historia [382; in octavo 14]. To imponujące dzieło (37 ksiąg; 2493 paragrafów) było próbą encyklopedycznego uporządkowania wiedzy z zakresu między innymi kosmologii, geografii, zoologii, botaniki i farmakologii.

Oprócz wymienionych jest jeszcze Historia rzymska Kasjusza Diona (Lucius Cassius Dio Cocceianus; 163/164-ok. 235) [382; in octavo 2] historyka greckiego pochodzenia, opisująca dzieje Rzymu od założenia do czasów Aleksandra Sewera, oraz wybór historycznych prac Ksenofonta (430 p.n. e.-355 p. n.e.) Historici opera [382; in octavo 4].

\section{Index Bibliothecae FF. Minorum Reformatorum: Conventus CRacoviensis ad} S. CASIMIRUM ANNo DromINI 1671

W indeksie z roku 1671 pozycji opisanych jako historyczne jest już 124 . Do spisu autorów starożytnych dołączają Plutarch (50-125) z dziełem, które określone jest enigmatycznie tytułem Historia (chodziło pewnie o którąs z jego prac biograficznych)

\footnotetext{
${ }^{2}$ K. Puchowski, Edukacja historyczna w jezuickich kolegiach Rzeczypospolitej (1565-1773), Gdańsk 1999, s. $142-160$.

${ }^{3}$ Za każdym przywołanym w tekście dziełem, które znajduje się w reformackim indeksie, umieszczona została adnotacja. Wszystkie zachowane XVII- i XVIII-wieczne indeksy przechowywane w bibliotece klasztoru św. Kazimierza w Krakowie zostały spięte razem i odręcznie (ołówkiem u góry strony) ponumerowane; jednak nie chronologicznie. W kwadratowym nawiasie umieszczonym po każdym przywołanym dziele podano więc stronę, format książki oraz liczbę, pod jaką widnieje w indeksie dana pozycja.
} 
[73; in folio 14 oraz 81; in duodecimo 10], Tacyt (ok. 55-ok. 120) z Rocznikami [75; in quarto 3], Ksenofont z Historia grecka, Kurcjusz Rufus (Quintus Curtius Rufus) jako autor De rebus gestis Alexandri Magni [81; in duodecimo 21], Korneliusz Nepos (100 p. n. e.-24 p. n. e.) i jego De vita excellentium imperatorum Graecorum ac Romanorum [81; in duodecimo 27] oraz Factorum et dictorum memorabilium libri IX - zbiór opowieści i maksym z historii głównie Rzymu i Grecji Waleriusza Maksymusa (1. połowa I w. n. e.) [81; in duodecimo 16].

Nie zabrakło klasycznej pozycji Tytusa Liwiusza Ab Urbe condita [73, in folio 16]. Znajdujemy dalej dzieło Gajusza Juliusza Solinusa (III wiek n. e.) Polyhistor rerum toto orbe memorabilium thesaurus locupletissimus [...] [73; in folio 2], mające charakter raczej geograficzny. Szczegółowy opis świata z naciskiem położonym na zjawiska niezwykłe i charakterystyczne cieszył się w XVI i XVII wieku znaczną popularnością. Dalej znajdujemy Justyna (Marcus Iunianus lub Iunianius; II lub III wiek n. e.) Historiae Philppicae [78; in octavo 19] oraz rzymskiego historyka Korneliusza Neposa (choć jego pracę przypisano gramatykowi o nazwisku Aemilius Probus i pod takim nazwiskiem widnieje w indeksie) De vitis excellentium Graeciae imperatorum [...] [81; in duodecimo 27].

Wśród autorów dzieł historycznych wymienieni są też Owidiusz i jego Metamorfozy (być może ze względu na ich quasi-historyczną strukturę) [81; in duodecimo 13] oraz Lukan (39-65) [81; in duodecimo 16], jako autor historycznej epopei Farsalii.

\section{HISTORYCY NOWOŻYTNI}

1. Index totius Bibliothecae Patrum Reformatorum Conventus Craconiensis ad SANCTUM CASIMIRUM ANNo DOMINI 1648

Co ciekawe, w księgozbiorze reformackim nie było prac historyków średniowiecznych. Mamy za to całą paletę historiografów XVI- i XVII-wiecznych. W indeksie najwcześniejszym jest ich jeszcze stosunkowo niewielu. Odnajdujemy więc postać Marco Antonio Cocci Sabellico (ok. 1436-1506), wybitnego humanistę i historyka, ucznia Pomponiusza Letusa, jako autora Enneades seu Rapsodiae historiarum [381; in folio 1], historii świata, jednego z pierwszych humanistycznych dzieł tego rodzaju. Warte odnotowania, że opisał w nim wyprawę Krzysztofa Kolumba do Nowego Świata. Windeksie z roku 1671 jest jeszcze inne jego dzieło Historia rerum venetarum ab orbe condita [73; in folio13]. Kolejna historia powszechna to głośna praca Horacego Turselliniego (1545-1599), jezuity. Jego zarys historii powszechnej nosi tytuł Historiarum ab origine mundi usque ad annum 1598 epitome libri X [...] [382; in duodecimo 2]. W kolegiach jezuickich był to podstawowy podręcznik do nauczania dziejów. Wielokrotnie wznawiany i uzupełniany pełnił przez 200 lat swą dydaktyczną funkcję (ostatnie wydanie $1786 \mathrm{roku})^{4}$. Można się domyślać, że także w kształceniu reformackim odgrywał podobną rolę.

\footnotetext{
${ }^{4}$ K. Puchowski, dz. cyt., s. 40-45.
} 
Dziełem, które na tym wczesnym etapie budowania księgozbioru znalazło się u reformatów, jest Argenis Johna Barclaya (1582-1621) [382; in octavo 5], alegorycznosatyryczny romans ukazujący społeczno-polityczną kondycję Europy XVII wieku. Ten głośny utwór przetłumaczony został na wiele europejskich języków. Na grunt polski przeniósł go Wacław Potocki.

W końcu mamy kilka prac polskich autorów. Są wśród nich Jan Herburt (ur. po 1524-1577) i jego Chronica sive historiae Polonicae compendiosa... descriptio, Pawła Potockiego (1. połowa XVII wieku-1675) kasztelana kamienieckiego, posła na sejm Historico-politicus sive quaestiones historicae et civiles [382; in duodecimo 6], przekład z Liwiusza dedykowany Władysławowi IV oraz Marcina Kromera (1512-1589) Monachus, sive colloquiorum de religione libri tres [382; in octavo 13] obszerny dialog będący katolickim komentarzem do gorących sporów z protestantami.

\section{Index Bibliothecae FF. Minorum Reformatorum: Conventus CRaCoviensis ad S. CASIMIRUM ANNO D`OMINI 1671}

Indeks z 1671 roku pokazuje, w jakim kierunku rozwijał się historyczny księgozbiór. Zgromadzone tam XVI- i XVII-wieczne prace układają się w pewne grupy, które spróbuje się tutaj wyodrębnić.

\section{a. Historie powszechne}

Wśród autorów dzieł mających ambicję opisać dzieje świata są Johann Ludwig Gottfried (1584-1633) protestancki teolog i jego dzieło Archontologia cosmica sive imperiorum, regnorum, principatuum rerumque publicarum omnium per totum terrarum orbem commentarii [73; in folio 4], Nicolaus Vernulaeus (Nicolaus de Vernulz), holenderski dramaturg, retor i historyk (1583-1649) autor Epitome Historiarum ab orbe condito ad haec usque tempora per monarchias quattuor deducta [75; in quarto 25] oraz Abraham Buchholzer (1529-1584), niemiecki teolog protestancki, historyk i pedagog, ze swoim dziełem Index chronologicus monstrans annorum seriem a mundo condito usque ad annum nati Christi [78; in octavo 1]. Dział ten zdominowany jest przez autorów protestanckich. Obok już wymienionych znajdujemy jeszcze głośne i wielokrotnie wznawiane dzieło Calendarium Historicum Paula Ebera (1511-1569) [75; in quarto 10], gdzie autor dokonał między innymi rewizji rzymskiego kalendarza, oraz Thesaurus chronologiae in quo universa temporum et historiarum series in omni vitae genere ponitur ob oculos luterańskiego profesora teologii i filozofii, bliskiego przyjaciela Melanchtona Johanna Heinricha Alsteda (1588/1589-1638) [75; in quarto 21]. Jego praca ma charakter encyklopedyczny, zbiera w niej autor prace ponad 500 autorów od starożytności po czasy mu współczesne.

\section{b. Historie państw i regionów}

Warta zauważenia jest też grupa prac poświęconych historii poszczególnych państw i regionów. I tak indeks odnotowuje takie pozycje jak: Historia Persica napisana przez 
Petro Bizari (?1530-?1586) [73; in folio 15], Historia Hispanica [78; in folio 24] autorstwa Andrea Bependi czy Disserti Belgii Chronicon [78; in octavo 28], Belgium confoederatum [81; in duodecimo 4] Elogia regum Boemiae [75; in quarto 31] czy w końcu Descriptio nova regni Sueciae [81; in duodecimo 7]. W przypadku ostatniego z wymienionych tekstów chodzi być może o utwór Regnorum Sueciae, Gothiae, Magnique Ducatus Finlandiae etc. Descriptio Nova, obejmujący więc nie tylko dzieje Szwecji, ale też innych państw skandynawskich.

W grupie tej można umieścić jeszcze tekst zatytułowany Scanderbergi Vita [78; in octavo 9-10]. Ta ostatnia pozycja, na co wskazuje określenie vita, to historia życia wielkiego albańskiego XV-wiecznego bohatera Skanderbega (Jerzy Kastriota, 1405-1468), który uważany był w Europie za wzór chrześcijańskiego władcy skutecznie stawiającego czoło otomańskiej inwazji. Jednym z najpopularniejszych dzieł jemu poświęconych była praca albańskiego historyka Marino Barlezio (ok. 1450-1512/1513), Historia de vita et gestis Scanderbegi Epirotarum principis.

Ostatnia pozycja wymieniona w tej kategori to Typus Gloriae Austriacae [...] Varia Poesi Exhibitus Johanna Marxa Reinharda [75; in quarto 13]. O tyle nietypowa na tle pozostałych, że jest to zbiór emblematów.

\section{c. Historia starożytna oczami humanistów}

Także historia starożytna opisywana przez pisarzy nowożytnych znalazła się w reformackim księgozbiorze. Wśród nich praca Francisco Poletti (w indeksie znajdujemy formę: Toletti) Historia fori Romani [78; in octavo 7] oraz Andrei Domenico Fiocchi, papieskiego sekretarza, De magistratibus et sacerdotiis Romanorum [81; in duodecimo 25]. Przy tym tytule figuruje Lucius Fenestella (52 p. n. e. -19 bądź 35/36 n. e.), rzymski historyk, pod którego nazwiskiem wydał swą pracę Fiocchi. Można tu wymienić również dzieło Icones Imperatorum Romanorum [73, in folio 5]. Widnieje przy nim nazwisko Gaspara Gevartiusa (1593-1666), uczonego, poety i krytyka. Był on autorem literackich komentarzy do portretów władców wykonanych ręką Huberta Goltziusa (1526-1583), słynnego artysty malarza, grafika i numizmatyka.

\section{d. Traktaty $\mathrm{z}$ teorii ustroju}

Zaskakująco dużo tekstów mieści się w grupie, którą określić można mianem teorii ustroju, przy czym wchodzą tu w grę zagadnienia prawnicze, ekonomiczne i polityczne.

Pierwszym tekstem, który można tu wymienić, jest Tractatus de antiquitatibus temporum [73; in folio 8]. Jego autor, profesor prawa, Włoch Aymone Cravetta (15041569), był doradcą księcia Sabaudii Emmanuela Filiberta. Jego praca, odwołując się do rzymskiego prawa, traktuje o spadkach i dziedziczeniu, o nabywaniu nieruchomości, a także o prawie feudalnym oraz statusie prawnym zamężnych kobiet.

Mamy tu także Gabriela Ackeleye XXV exercitationes, sive politico-philologici discursus in librum C. Cornelii Taciti de moribus Germanorum veterum [78; in octavo 29]. 
Inspirował się autor dziełem Tacyta o charakterze etnograficznym De origine et situ Germanorum. Jedyny egzemplarz odnaleziony w XV wieku, był niezwykle popularny wśród humanistów (Piccolomini, Celtis), widzących w nim wiarygodne źródło do dziejów starożytnej Germanii. Posłużył on jako źródło inspiracji do politycznych rozważań o państwie.

Kolejny autor to Adam Contzen (1571-1635) niemiecki jezuita, który zajmował się teologią kontrowersyjną, egzegezą, ale i ekonomią. W tej ostatniej dziedzinie zasłynął przede wszystkim pracą Politicorum libri X. Określano go jako anty-Machiavellego, ponieważ w swej pracy opisał ideał władcy chrześcijańskiego, postępującego zgodnie z nauką Kościoła. Omówił w tej pracy też szczegółowe kwestie polityczne, dotyczące gospodarki, podatków (postulował ich reformę). Traktat ten miał niejako swoją kontynuację. Contzen napisał bowiem powieść polityczną Methodus doctrinae civilis seu Abissini regis historia [75; in quarto 26], w której próbował pokazać praktyczne zastosowanie swoich teorii. Odnotowana została ona w reformackim indeksie z 1671 roku. Warto jednak dodać, iż w indeksie z roku 1689 są jeszcze inne prace tego autora. Obok wspomnianego przed chwilą Politicorum libri $X$, jest jeszcze De statu vita et virtute aulicorum. To rodzaj speculum, opisującego cechy dobrego dworzanina [114; 125-128]. Adam Contzen wielce cenił polityczne koncepcje Justusa Lipsjusza. To właśnie fundamentalne dzieło wielkiego humanisty Politicorum, sive Civilis doctrinae libri sex zainspirowało niemieckiego jezuitę i jego Politicorum libri X. Był on też inicjatorem pomysłu, aby dzieła polityczne Lipsjusza stały się elementem jezuickiej edukacji'.

Politicorum, sive Civilis doctrinae libri sex Lipsjusza (1547-1606) [81; in duodecimo 9] także znalazło się w reformackim zbiorze. Uznawane za fundamentalne wśród zwolenników idei monarchii absolutnej, od pierwszego wydania w 1589 roku do połowy XVIII wieku miało ponad pięćdziesiąt wydań. Przetłumaczono je na 24 języki ${ }^{6}$. To obszerna praca, w której autor, bazując na dziełach przede wszystkim filozofów i historyków od starożytności począwszy, tworzy własną „teologię” polityczną. Pierwsze dwie księgi to wizerunek idealnego władcy, trzecia i czwarta traktują między innymi o urzędach, instytucjach państwowych, stosunku państwa do religii, mechanizmach rządzących wspólnotą. Piąta podejmuje kwestie strategii militarnych, armii i dowództwa. Szósta zaś rozwija kluczowe pojęcie dla Lipsjuszowego pojmowania mądrej działalności politycznej — prudentia (roztropność) ${ }^{7}$.

\section{e. Teksty satyryczne}

Warto odnotować obecność dwóch tekstów o charakterze politycznej satyry. Pierwszy to Lapis Lydius politicus Trajano Boccaliniego (1556-1613) [81; in duodecimo 3], w indeksie widniejący omyłkowo jako Rozalini. Lapis Lydius jest łacińską wersją tekstu, który został napisany po włosku, a zatytułowany był Pietra del paragone politico. Był

\footnotetext{
${ }^{5}$ J. Dąbkowska-Kujko, Justus Lipsjusz i dawne przektady jego dziet na jezyk polski, Lublin 2010, s. 201-202.

${ }^{6}$ Tamże, s. 199.

${ }^{7}$ Tamże, s. 202-205.
} 
on ostrą satyrą na świat polityki, pozbawioną złudzeń co do mechanizmów rządzących nią i demaskującą je. Stawia się autora i jego myślenie o politycznych mechanizmach po przeciwległej stronie wobec myślenia takich utopistów jak Tomasz Campanella czy Franciszek Bacon.

W indeksie, co ciekawe, odnajdujemy także ostrą antyjezuicką satyrę Monarchia solipsorum [78; in octavo 26-27]. Jako autor widnieje niejaki Lucius Cornelius Europaeus. Jest to jednak pseudonim. Autor to najprawdopodobniej eksjezuita Jules Clément Scotti (1602-1669), choć czasem autorstwo przypisywano Melchiorowi Inchoferowi, którego nazwisko pojawiło się w kolejnych wydaniach. Tekst wywołał duże poruszenie. Jezuitów opisano jako tajne stowarzyszenie „Solipsen”, które ma ambicje posiadania wszechwładzy. Autor był przekonany, że demaskuje ich hipokryzję i rządzę władzy. Doskonałą egzemplifikacją zawartości jest ilustracja i komentarz do niej, które można znaleźć na początku francuskiego wydania z roku 1824. Przedstawia ona kameleona, a pod spodem słowa: „Caméléon est donc l'emblème de ces hypocrites qui prennent la manière de penser et d'agir des hommes puissants, et qui en changent toutes les fois que cela leur parait nécessaire pour assouvir leur vile ambition"8.

\section{f. Epistolografia}

Dział historyczny uwzględnia również epistolografię. Dwa niezwykle ciekawe zbiory listów. Pierwszy to Epistolae familiares Eneasza Sylwiusza Piccolominiego (później papieża Piusa II, 1405-1464) [75; in quarto 29], to listy poruszające różne tematy (osobiste, filozoficzne, poetyckie historyczne). Są one doskonałym źródłem informacji o XV-wiecznej Europie, zwłaszcza o charakterze politycznym i religijnym.

Autorem kolejnego zbioru listów jest Jean Tixier de Ravisi (1480-1524), francuski humanista, retor, erudyta i wybitny znawca kultury antycznej (Epistolae Joannis Ravisii Textoris, Non vulgaris Eruditionis [81; in duodecimo 29]).

\section{g. Czasopismo}

Intryguje kolejna pozycja. To jedno z pierwszych czasopism, jakie zaczęły ukazywać się w Europie, Mercurius Gallo-Belgicus; sive Rerum in Gallia et Belgio potissimum: Hispania quoque, Italia, Anglia, Germania, Polonia [...] [78; in octavo 11-12]. Wydawane było co pół roku, dystrybuowane na targach książki 1594-1638. Rzecz ma charakter szczegółowego opisu kolejnych znaczących politycznych, społecznych, militarnych i gospodarczych wydarzeń, które miały miejsce w danym roku.

\section{h. Polscy pisarze historyczni}

Dobrze wyposażony był reformacki księgozbiór w prace polskich historyków. Uwzglednione były tutaj teksty zarówno polsko-, jak i łacińskojęzyczne. Nie zabrakło żadnego z kluczowych dzieł polskiego dziejopisarstwa. Mamy więc Jana Długosza (1415-1480) Annales seu cronicae incliti Regni Poloniae [73; in folio 9], Chronica

\footnotetext{
${ }^{8}$ J. C. Scotti, La Monarchie des Solipses, Paris 1824, s. 8.
} 
Polonorum Macieja Miechowity (1457-1523) [73; in folio 10], Annales Stanisława Orzechowskiego (1513-1566) [78; in octavo 13], De origine et rebus gestis Polonorum libri XXX Marcina Kromera (1512-1589) [73; in folio 6].

Szymon Starowolski pojawia się jako autor dzieła metahistorycznego Penu historicum [78; in octavo 4]. Traktat wydany został w 1620 roku. Autor powołuje się w nim na autorytet przede wszystkim Justusa Lipsjusza oraz jego ucznia Jana Bernartiusa i jego dzieła De utilitate legendae historiae libri duo. Szeroko wywodzi w nim o pożytkach płynących ze znajomości historii, traktuje o metodologii prac historycznych, udziela rad czytelnikom dzieł historycznych.

Korzystający z reformackiego księgozbioru mogli także poznać praktyczną stronę historycznego oratorstwa, biorąc do ręki mowy Krzysztofa Warszewickiego (15431603) oraz Ossolińskiego, zapewne Jerzego. Przy nazwisku tego pierwszego mamy enigmatyczną formułę Oratio [75; in quarto 15]. Trudno więc powiedzieć, o którą z jego licznych mów chodzi. Najsłynniejsze to De laudibus Ioannis Tarnovii [...] Oratio; Ad Stephanum Regem Poloniae Oratio; In obitum Stephani I Regis Poloniae oratio; In mortem Annae Austriacae Poloniae Sueciae Reginae oratio. Przy nazwisku Ossolińskiego pojawia się zaś określenie Orationes [75; in quarto 7]. Jerzy Ossoliński (1595-1650) kanclerz wielki koronny, słynny mówca, którego oracje znane były w całej Europie (np. Oratio ad Jacobum I Britaniae Regentem Londini nomine Sigismundi III auxilium adversus barbaros poscendo czy Oratio ad Ferdinandum septemvirosque Sracri, Rromani, Irmperii, Principes congregatos Ratisbonae). Być może termin „orationes” (umieszczony przy jego nazwisku) odsyła do jego zbioru mów wydanego w 1647 roku zatytułowanego Orationes habitae apud Summum Pontificem, Imperatorem, Reges, Principes et Venetam Rempublicam cum nomine duorum Regum Septemtrionis maximorum Sigismundi III Patris, et Vladislai IV filii [...].

Kolejna grupa, o której należy wspomnieć, to teksty będące reakcją czy zapisem rozgrywających się współcześnie wydarzeń. Można je w jakiejś mierze nazwać literaturą okolicznościową. Są wśród nich takie prace jak Samuela Kazimierza Kuszewica (1607-1666) Narratio Legationis Zbaravianae et rerum apud Ottomanos [81; in duodecimo 8], historia poselstwa księcia Zbaraskiego do Turcji; Carcer Gallicus [75; in quarto 8] Ewerharda Wassenberga (1610-1667), historiografa na dworze Zygmunta Wazy, opisujące uwięzienie we Francji królewicza Jana Kazimierza (Carcer Gallicus to rodzaj tematycznego wypisu z jego dzieł historycznych). Do międzywyznaniowych sporów nawiązuje praca znanego antyariańskiego polemisty, jezuity, Mikołaja Cichowskiego (1594-1669) Speculum Samosathenistarum; vel Socianistarum; vulgo Arrianorum [...] [75; in quarto 18]. Był to polemista niezwykle ostry i napastliwy. Przyczynił się wydatnie do wydania i utrzymania dekretu banicyjnego dotyczącego arian?

Wśród polskich pisarzy historycznych mamy jeszcze Opuscula Zawackiego (to formuła z indeksu) [81; in duodecimo 19]. Wydaje się, że chodzi o Teodora Zawadzkiego

${ }^{9}$ Zob. hasło: Cichowski Mikołaj, [w:] Encyklopedia wiedzy o jezuitach na ziemiach Polski i Litwy 15641995, oprac. L. Grzebień SJ przy współpracy zespołu jezuitów, Kraków 2004, s. 99. 
(Zawackiego) autora popularnego traktatu rolniczego, rodzaju gospodarskiego kalendarza Memoriale oeconomicum. Pozostawił on po sobie także pisma z zakresu prawa oraz jego historii. Trudno powiedzieć, czy sporządzający indeks pisząc „Opuscula” miał na myśli kilka dzieł Zawadzkiego, które znajdowały się w księgozbiorze, a których tu nie wyszczególnił, czy może chodziło mu na przykład o dzieło zatytułowane Processus ludicarius Regni Poloniae. Opera Theodori Zawacki, Ex Familia Rogala, Equitis Poloni (1612).

Ostatnie dwa teksty, które zostaną tu przywołane, to Idea Apocaliptica seu Apocalipsis Stanislai Orichovii in qua Facies perturbatae et afflictae Reipublicae ejusque restaurandae ratio repraesentatur. Dzieło - co sugeruje sam tytuł - figuruje przy nazwisku Orzechowskiego [81; in duodecimo 2]. Pracę tę bowiem długi czas przypisywano właśnie temu pisarzowi, podczas gdy dziś wiadomo, że jej autorem był Jan Dymitr Solikowski (1539-1603). To inspirowany apokaliptycznymi wizjami św. Jana obraz współczesnej Polski i grożących jej niebezpieczeństw. Kolejny tekst, będący tym razem poetyckim zapisem historycznego wydarzenia, to Nowa Gigantomachia [75, in quarto 4] Augustyna Kordeckiego (1603-1673). Autor, przeor jasnogórkiego klasztoru, dowodzący jego obroną w trakcie szwedzkiego najazdu (1655), opisał w nim dzieje oblężenia częstochowskiego sanktuarium.

Na koniec warto wspomnieć, że księgozbiór uwzględniał także Statuta Regni Poloniae [73; in folio 24-25], zbiór norm prawnych Rzeczypospolitej Jana Herburta (Statuta Regni Poloniae in ordinem alphabeti digesta).

Pierwszy odnotowany stan klasztornego księgozbioru z 1648 roku, choć jeszcze stosunkowo ubogi, pozwala już wyznaczyć zasadnicze pola historiograficznych zainteresowań zakonu, a chyba też profil historycznego kształcenia. Pierwsze, co daje się zauważyć, to nacisk położony na poznanie historiografii starożytnej. Nie można zapominać, że dzieła historyczne, zwłaszcza starożytne, pełniły rolę służebną wobec retoryki. Wykorzystywano je przede wszystkim jako źródło przykładów w ćwiczeniu retorycznych umiejętności. W tym jeszcze niewielkim pierwszym opisanym księgozbiorze nie brakuje prawie żadnego nazwiska z czołówki rzymskich historiografów. Warto odnotować brak zainteresowania historiografią średniowieczną. Pojawiają się za to, choć jeszcze nieliczni, przedstawiciele historiografii renesansowej. Znamienna jest obecność pracy jezuity Horacego Turselliniego, który (o czym była już mowa) miał ogromny wpływ na kształt historycznego kształcenia jezuitów. Być może i u reformatów pełnił podobną funkcję.

Zaledwie trzy nazwiska polskich autorów: Pawła Potockiego (Historico-politicus sive quaestiones historicae et civiles), Marcina Kromera (Monachus, sive colloquiorum de religione libri tres) oraz Jana Herburta (Chronica sive historiae Polonicae compendiosa... descriptio) mogą sugerować brak zainteresowania polską historiografią. Indeks z roku 1671 pozwala zweryfikować te obserwacje.

Coraz bardziej okrzepły na polskim gruncie zakon reformatów, pozyskujący nowe klasztory, z coraz większą liczbą kandydatów do służby zakonnej doskonalił także system kształcenia przyszłych zakonników. Księgozbiór z 1671 roku odzwierciedla ten 
stan. Jego kształt, jeśli chodzi o dział historyczny, nie odbiega już zawartością od modelowych pod tym względem księgozbiorów jezuickich.

Jedna z różnic jest jednak zasadnicza i znacząca. Wśród historii powszechnych poza Tursellinim mamy tylko prace protestantów: Johanna Ludwiga Gottfrieda, Nicolasa Vernulaeusa, Abrahama Buchholzera, Paula Ebera, Johanna Heinricha Alsteda. Kluczowym okazało się więc nie kryterium wyznaniowe, lecz merytoryczne, historiografia uprawiana przez protestantów stała bowiem na wysokim poziomie. W tym czasie, kiedy stosunki między katolikami a protestantami były bardzo napięte, wzajemna niechęć, czasem nienawiść, przekładały się na nieufność wobec naukowego dorobku przeciwników, nawet jeśli był on pozbawiony konfesyjnej perspektywy.

Zwraca uwage, jak wiele dzieł w dziale Libri historici to prace z zakresu geografii. Umieszczenie ich „tutaj” to świadectwo ówczesnych przekonań pedagogicznych, wedle których historia łączyć się powinna z wiedzą geograficzną i chronologią („,dwojgiem oczu historii" - jak je nazywano ${ }^{10}$. Chronologię reprezentują prace Abrahama Buchholzera oraz Johanna Heinricha Alsteda. Za najwybitniejszego przestawiciela tej ostatniej dziedziny katolicy uznawali Dionizjusza Petawiusza i jego dzieło De doctrina temporum. Znajdziemy je w reformackim indeksie z 1689 roku [s. 116; 27-28 ${ }^{11}$.

Przegląd zawartości reformackiego księgozbioru (w zakresie dzieł historycznych) pokazuje tendencje, jakie panowały w XVII-wiecznej dydaktyce. Bazowano już nie tylko czy nie przede wszystkim na historiografach starożytnych, ale coraz szersze zainteresowanie wzbudzali historiografowie nowożytni. Charakterystyczne było również postrzeganie historii w powiązaniu z takimi dziedzinami jak, z jednej strony, geografia i chronologia, z drugiej — prawo, ekonomia, filozofia czy polityka, z trzeciej zaś numizmatyka i emblematyka. Coraz mocniejszy nacisk kładziono na dzieje narodowe. Stąd też coraz większy udział w księgozbiorze polskich historyków. Biblioteka reformacka posiadała prawie wszystkie znaczące dzieła polskich historiografów, począwszy od Długosza, poprzez autorów renesansowych, aż po twórców XVII-wiecznych.

The Historical Works in the XVIIth Reformati Library of S. Casimir Monastery in Cracow

Summary

This article is the analysis of two library indexes. The inventories date from the XVII ${ }^{\text {th }}$ century (1648 and 1671); it describes ownership of library of Cracow monastery S. Casimir. It was a monastery of members of The Order of the Reformati. Each of them contains a historical section "libri historici". Within them are libri historici sacri and libri historici profani. Here are described historia profana. The first analysis has been dedicated to works of ancient authors, and then - modern. The book collections do not miss any of the leading writers of antiquity (e.g. Titus Livius, Suetonius, Julius Caesar, Plinius Secundus, Tacitus, Plutarchos). Works of modern authors were divided into the following parts: General history, History of countries and regions, Ancient history through the eyes of humanists, Treatises of the theory of system, Satirical works, Epistolary, Periodicals, Polish historical writers. The arrangement of the material is in such a way that is reveals main historical areas of interest of contemporaries.

\footnotetext{
${ }^{10}$ K. Puchowski, dz. cyt., s. 105.

${ }^{11}$ Index Totius Bibliothecae PP. Reformatorum [...] Anno Domini 1689 [...].
} 